\title{
Soaking Time and Temperature on Condensed Tannin and Phytic Acid of Soybean Products
}

\author{
Zeritu Shashego \\ Southern Agricultural Research Institute, Hawassa Agricultural Research Center, \\ P.O. Box 06, Hawassa, Ethiopia
}

\begin{abstract}
To enrich the diet, soybean plays great role by reducing protein malnutrition by substituting animal protein. However, the major problems in raw soybeans are off flavor and anti-nutritional factors. Processing also affect nutritional value unless optimum processing methods are used. Thus, this investigation was carried out to evaluate the effect of soaking temperature and time on anti-nutritional factors (phytic acid and condensed tannins) made from soybean variety AFGAT (Glycine max). Two soaking temperatures hot water $\left(40^{\circ} \mathrm{C}\right)$ and ambient temperature $\left(25^{\circ} \mathrm{C}\right)$ and three soaking times $(8,12$ and $16 \mathrm{hrs})$ were considered in the experiment. The study revealed that soaking time and temperature had significantly $(\mathrm{p}<0.05)$ affected on anti-nutritional factors. Soy flour condensed tannin was significantly $(\mathrm{p}<0.05)$ higher $\left(0.23 \mathrm{mg} \mathrm{CE} \mathrm{g}^{-1}\right)$ at $16 \mathrm{hrs}$ soaking time with $40^{\circ} \mathrm{C}$. The values exhibited reduction in condensed tannin $\left(0.03 \pm 0.01 \mathrm{mg} \mathrm{CE} \mathrm{g}{ }^{-1}\right)$ soaking at $8 \mathrm{hrs}$ for $40^{\circ} \mathrm{C}$. The soaking time and temperature showed reduction in condensed tannins from $0.29 \mathrm{mg} \mathrm{CE} \mathrm{g}^{-1}$ (raw) to $0.02 \mathrm{mg} \mathrm{CE}$ $\mathrm{g}^{-1}$. Higher $\left(9.17 \mathrm{mg} \mathrm{g}^{-1}\right)$ soy flour phytic acid was observed at $12 \mathrm{hrs}$ soaking time with $40^{\circ} \mathrm{C}$. Increased in the level of phytic acid from $4.11 \mathrm{mg} \mathrm{g}^{-1}$ (raw) to maximum $9.17 \mathrm{mg} \mathrm{g}^{-1}$ (soaked for $12 \mathrm{hr}$ at $40^{\circ} \mathrm{C}$ ) in flour was observed. Soy milk condensed tannin was also affected by soaking time and temperature and ranged from 0.07 to $0.24 \mathrm{mg} \mathrm{CE} \mathrm{g}^{-1}$ for soybean soaked for $8 \mathrm{hrs}$ at $25^{\circ} \mathrm{C}$ and $40^{\circ} \mathrm{C}$ and for soybean soaked for $16 \mathrm{hrs}$ at $25^{\circ} \mathrm{C}$, respectively. The higher soy milk phytic acid was $8.31 \mathrm{mg} \mathrm{g}^{-1}$ for soybean soaked for $8 \mathrm{hrs}$ at $25^{\circ} \mathrm{C}$. The phytic acid was decreasing when the soaking time increases at lower temperature. In conclusion the anti-nutritional factors of soybean flour and milk were influenced by soaking time and temperature. The result obtained suggests that good quality soybean flour and soybean milk can be obtained from soybean soaked for $8 \mathrm{hrs}$ at $40^{\circ} \mathrm{C}$.
\end{abstract}

Keywords: Anti-nutritional factors, Soaking time, temperature, Soybean, Soy flour, Soy milk

DOI: $10.7176 / \mathrm{FSQM} / 85-02$

Publication date:March $31^{\text {st }} 2019$

\section{Introduction}

The soybean (Glycine max (L) Merrill, family Leguminosae) is important source of high quality, inexpensive protein than other legumes and about $35-38 \%$ of its calories are derived from its protein as compared to $20-$ $30 \%$ in most other beans. Protein rich source of other legume is high in cholesterol and saturated fat whereas, soybean foods provide high quality protein, cholesterol free and low in saturated fat, equivalent to animal protein in its protein quality and higher than other plant proteins (FAO, 1990). Among soybean products, soy flour is made from whole or dehulled soybeans. Soy flour had protein content between 35 and $40 \%$ and a fat level between 15 and $20 \%$. It is extremely nutritious and high in fiber and contains all of the vitamins, minerals, and phytochemicals of soybeans. Soy milk is an emulsive liquid extracted from soybean and it is recognized as milk from vegetable due to its high protein and fat content and the homogeneous form in texture resembling animal milk. The protein and fat content ranges from 39 to $46 \%$ and 16 to $18 \%$, respectively, based on variety.

Soy milk is cholesterol free and low fat produced from soaked soybean. The nutritional value of soy milk can be compared with that of cow's milk. Soy milk contains higher protein than cow's milk (Hurrell et al., 1992). Soy milk containing good quality protein, fat, isoflavones, vitamins, minerals and carbohydrate has attracted a great deal of public attention as a healthy food and a good choice for people who are lactose intolerant, in which $75 \%$ of the world population have no ability to digest lactose that causes stomach cramp, flatulence and diarrhea (Riaz, 2006). Also it is a good alternative to those who are allergic to the proteins of cow's milk,

However, utilization of soybean as food is often limited due to the presence of ANFs that are known to exert a deleterious effect when ingested by humans or animals. ANFs are compounds that impair health by destroying nutrients or by reducing the uptake of such essential elements and giving astringent test, odor, flavor and cause adverse physiological responses that would lead to diminished availability of certain nutrients. ANFs also interfere with growth, reproduction, or health and reduce protein, mineral and carbohydrate utilization when consumed regularly even in normal amounts (Bahnassey et al., 1986).

Phytic acid lowers the bioavailability of certain minerals through formation of insoluble complexes at intestinal pH (Erdman, 1979). Phytic acid decreases the availability of zinc, manganese, copper, molybdenum, calcium, magnesium, iron as well as protein digestion (Maga 1982; Beleia et al., 1993). When bound to protein, it induces decrease of solubility and functionality of the protein (De Khano and Jost, 1979). Tannins are 
polyphenolic compounds, which decrease the protein quality (digestibility) of foods and interfere with dietary minerals (Fe, Zn, Ca, Mg) absorption (De Lumen and Salamat, 1980).

The ANFs can be fully or partially removed by pretreatments (Harmuth-Hoene, et al., 1987), including blanching, soaking, dehuling, germination, fermentation and cooking can greatly influence protein digestibility and palatability and improve nutritive value of soybean products (Wang, et al., 2003). Therefore, search for suitable soy milk and soy flour processing methods that can be locally adapted, improve the nutritional quality through suppressing the anti-nutritional factors and off flavor nature coupled with better nutrient extraction are required for proper utilization of soybean flour and milk in Ethiopia.

\section{Materials and Methods}

This experiment was conducted at Haramaya university in 2010. Improved soybean variety named AFGAT [TGX-1892-10F], was used. This variety was selected due to its relatively lower price, good productivity and high nutritional composition. For ensuring the quality, the breeder seed was used. The experiment comprised two factors (soaking times and temperatures) arranged in CRD with three replications. Soaking time had three levels $(8,12$ and $16 \mathrm{hrs})$ and two soaking temperatures, 25 and $40^{\circ} \mathrm{C}$.

The clean seed samples were immersed in to thermostatically controlled hot water bath for 10 seconds at $91^{\circ} \mathrm{C}$ with a ratio of soybean grain to water of 1:3 to suppress the soybean lipoxygenase enzyme activity (Brown et al., 1982). As soon as the blanching was completed the samples were withdrawn and immediately cooled down in cold water at ambient temperature for 15 seconds. The blanched samples were soaked in tap water for 8 $\mathrm{hrs}, 12 \mathrm{hrs}$ and $16 \mathrm{hrs}$ at ambient temperature $\left(25^{\circ} \mathrm{C}\right)$ and hot water $\left(40^{\circ} \mathrm{C}\right)$ using thermostatically ontrolled water bath. The soaked samples were dried in direct sunlight. The seed coats and germs were then removed manually using stone grinder. The dehulled beans were milled for further analyses.

The untreated sample (control) which was used for comparison was cleaned manually to remove physical impurities such as foreign matters, immature and damaged seeds. The cleaned soybean was milled using Professional Burr mill and the flour was sifted to pass through 710 micron test sieve. The sample was sealed in moisture proof plastic bag and stored at room temperature until laboratory analysis were conducted (Nwabueze, 2007). The grain flour was analyzed for anti-nutritional factors (phytic acid and condensed tannins) to compare with the treated samples.

Treated soy flour preparation:- Soybean was cleaned from physical impurities and thoroughly washed with soft water, then it was blanched. One kg blanched soybean was soaked in 2 litter hot water $\left(40^{\circ} \mathrm{C}\right)$ and $25^{\circ} \mathrm{C}$ in each plastic container for . 8, 12 and 16 hours. After pouring off the water, the soybean was rinsed with water (Hymowitz and Polmer 2004). Part of each soaked soybean were dried in direct sun light and dehulled manually using stone grinder. The dehulled beans were manually separated from the hull and milled to flour using laboratory mill.

Soy milk preparation: - Soy milk was prepared from soaked soybean by using Japanese method using the main soy milk maker. (Soy wonder Soymilk Machine, Model MJ 720) for each grinding time (10 min) to produce slurry. The slurry was heated near boiling temperature and the soluble soy milk emulsion was readily separated from the insoluble residue (okara) by passing the slurry through a fine filter cloth (cheese cloth). The filter cloth was folded four times to reduce entrance of unwanted materials to the extracted soy milk (Nwabueze, 2007). The soy milk was boiled at $90^{\circ} \mathrm{C}$ for 18 minutes to reduce trypsin inhibitor and to retain nutritive value of the product (Camire, 2001). Soy milk was analyzed for its anti-nutrient composition.

The soymilk sample were dried in two stage drying in an oven (Incubators Circulation air natural, Binder $\mathrm{GMBH}$ ) at a temperature of $70^{\circ} \mathrm{C}$ and $100^{\circ} \mathrm{C}$ for $16 \mathrm{hrs}$ and $1 \mathrm{hrs}$, respectively. The soybean milk powders were sealed in moisture proof plastic bag and analyzed foranti-nutritional factors (condensed tannins and phytic acid).

\subsection{Anti-nutritional Factors Analysis Methods}

Condensed tannin was determined by the Vanillin- $\mathrm{HCl}$ method (Price et al., 1978). A $0.2 \mathrm{~g}$ was milled to pass 750 micron test sieve and extracted with $10 \mathrm{ml}$ methanol by vortex mixing for $20 \mathrm{~min}$ in rotating screw cap tubes $(13 \times 100 \mathrm{~mm})$. The mixture was then centrifuged for 10 minutes at 3500 revolution per minute (rpm) and the supernatant was used in the analysis. A $0.0,0.2,0.4,0.6,0.8$ and $1.0 \mathrm{ml}$ aliquots of catechin standard were dispensed into two sets of tubes and each sample was brought to $1.0 \mathrm{ml}$ by the addition of methanol. Incubating the tubes in the water bath at $30^{\circ} \mathrm{C}, 5 \mathrm{ml}$ of the working vanillin reagent was added at $1 \mathrm{~min}$ interval to one set of standards, and $5 \mathrm{ml}$ of the $4 \% \mathrm{HCl}$ in methanol solution was added at $1 \mathrm{~min}$ intervals to the second set of standards. Sample extract was also treated as for the standard. The samples in a water bath were kept for 20 min at $30^{\circ} \mathrm{C}$, and the absorbance at $500 \mathrm{~nm}$ was read using spectrophotometer. The absorbance of the blank was subtracted from the absorbance of the corresponding vanillin-containing sample . A standard curve was constructed (absorbance vs. catechin) and the linear portion of the curve was extrapolated to produce the standard curve. Using the sample absorbance data the condensed tannin contents were estimated from the calibration curve. 
Phytic acid was determined through phytate phosphorus (Ph-p) analysis. A $0.25 \mathrm{~g}$ of flour sample was extracted with $12.5 \mathrm{ml}$ of 3\% trichloroacetic acid for $45 \mathrm{~min}$ in a shaking water bath with vortex mixing at an ambient temperature $\left(23^{\circ} \mathrm{C}\right)$ and centrifuged $(4000 \mathrm{rpm} / 10 \mathrm{~min})$. The extract supernatant $(10 \mathrm{ml})$ was taken for phytate estimation. A $4 \mathrm{ml}$ of $\mathrm{FeCl}_{3}$ (that contain $2 \mathrm{mg} \mathrm{Fe}{ }^{3+}$ ion per $\mathrm{mL}$ in $3 \%$ TCA) was added to $10 \mathrm{ml}$ of the sample solution to get the phytate-Fe precipitate and centrifuged. The clear supernatant was carefully decanted and the precipitate was washed by $20 \mathrm{ml}$ of $3 \% \mathrm{TCA}, 0.2 \mathrm{ml}$ of $\mathrm{HCl}$ and $20 \mathrm{ml}$ distilled water. The precipitate was digested by concentrated $\mathrm{H}_{2} \mathrm{SO}_{4}$ in the presence of 3-4 drops of $\mathrm{H}_{2} \mathrm{O}_{2}(30 \%)$ at $350^{\circ} \mathrm{C}$. When the digestion was complete the sample was cooled to room temperature and sodium sulfite $(0.4 \mathrm{ml}, 33 \%)$, ammonium molybdate $(3 \mathrm{ml}, 2 \%)$ followed by L-ascorbic acid $(2 \mathrm{ml}, 2 \%)$ was added. The sample was heated in a boiling water bath for 10 minutes to get the blue color. After cooling to ambient temperature, it was adjusted to a volume of $20 \mathrm{ml}$. The absorbance of the blue color developed was measured at $822 \mathrm{~nm}$ using spectrophotometer. The absorbance for sample was subtracted from the blank. A standard calibration curve was constructed from $0.1 \mathrm{mg}$ $\mathrm{KH}_{2} \mathrm{PO}_{4}$ dissolved in $250 \mathrm{ml}$ distilled $\mathrm{H}_{2} \mathrm{O}$. Aliquots $0.0,0.4,0.8,1.2,1.6,2.0$ and $2.4 \mathrm{ml}$ form the stock were diluted to $20 \mathrm{ml}$ water. After the blue color was developed, absorbance was measured for the sample. The phosphorus level was estimated from the calibration curve. Then phytate level was estimated from phytate phosphorus value by multiplying with 3.55 .

\subsection{Statistical Analysis}

All data were analyzed using two factors analysis of variance (ANOVA). The Duncan's multiple- range test was used to establish the multiple comparisons of mean values. Mean values were considered at $5 \%$ significance level $(\mathrm{p}<0.05)$. The statistical analyses of the data were conducted using SAS statistical software package.

\section{RESULTS AND DISCUSSIONS}

Raw soya flour (control) condensed tannins content was $0.29( \pm 0.01) \mathrm{mg} \mathrm{CE} \mathrm{g}^{1}$. This value was higher compared to the value reported by Yimer and Admassu (2008) for raw Awassa soybean variety (0.19 $\left.\mathrm{mg} \mathrm{CE} \mathrm{g}^{1}\right)$ and Belessa variety $\left(0.08 \mathrm{mg} \mathrm{CE} \mathrm{g}^{1}\right)$. The phytic acid in raw soybean flour (control) was $4.11( \pm 0.23) \mathrm{mg} \mathrm{g}^{-1}$. This value was less than the phytic acid contents of raw Belesa soybean variety $\left(12.33 \mathrm{mg} \mathrm{g}^{-1}\right)$ reported by Yimer and Admassu (2008). This difference might be due to variety. Elfatio et al., (2003) stated that the amount of antinutrient is different in different variety of soybean.

\subsection{Soaking Temperature and Time on Tannin and Phytic acid content of Soybean Flour 3.1.1. Condensed tannins}

The effects of temperature on condensed tannin content of processed soy flour are presented in Table 5. The condensed tannin content of soy flour showed significant $(\mathrm{p}<0.05)$ difference with soaking temperature. The soybean subjected to soaking at $40^{\circ} \mathrm{C}$ was higher $\left(0.09 \mathrm{mg} \mathrm{CE} \mathrm{g}^{-1}\right)$ than those soybeans soaked at $25^{\circ} \mathrm{C}$ with mean condensed tannin content of $0.06 \mathrm{mg} \mathrm{CE} \mathrm{g}^{-1}$. The result agreed with Yimer and Admassu (2008). The result for condensed tannin obtained by these authors was almost the same as the result obtained in this study. Slight difference was due to the use of different legume varieties and processing. With the origin of the grain being different, it might be possible that the amount and nature of condensed tannin were also different.

In the present study the seeds were dehulled after blanched and soaked which might have changed the distribution of condensed tannin in the seeds. Treated soy flour contained less amount of condensed tannin compared with raw soy flour $\left(0.29 \mathrm{mg} \mathrm{CE} \mathrm{g}^{-1}\right)$. The result indicated that soaking temperature affect the condensed tannin content because condensed tannins were found on the outer covering of the seed and around testa with low or negligible amounts located in the cotyledons which could be reduced by processing. Adewusi and Osuntogun (1991) described that the most effective treatment to reduce tannins in soybean, cowpea and ground bean is soaking and dehulling. The hull is much richer in tannins than the whole seeds with cowpea hulls having as high as $4.13 \mathrm{mg}$ catechin equivalent/g. Soaking and dehulling of beans is the most efficient practice to remove the tannins by $95 \%$.

The effect of soaking time on condensed tannin content of soy flour was significant $(\mathrm{p}<0.05)$ and presented in Table 5. At $16 \mathrm{hrs}$ soaking time the condensed tannin content of soy flour was higher $\left(0.13 \mathrm{mg} \mathrm{CE} \mathrm{g}^{-1}\right)$. The lower value $\left(0.03 \mathrm{mg} \mathrm{CE} \mathrm{g}^{-1}\right.$ ) was obtained from $12 \mathrm{hrs} \mathrm{soaking} \mathrm{time.} \mathrm{This} \mathrm{result} \mathrm{agreed} \mathrm{with} \mathrm{those} \mathrm{of} \mathrm{Mubarak}$ (2005) who found that tannin content of mung bean reduced after water soaked for $12 \mathrm{hrs}$. These values were lower than raw soybean condensed tannin $\left(0.29 \mathrm{mg} \mathrm{CE} \mathrm{g}^{-1}\right)$. Legumes soaked for longer period of time reduce tannins because tannin is located in seed hull around testa and dehulling processes are expected to reduce its levels but extended time may result the condensed tannin reabsorbed by the seed. Since condensed tannins are located mainly in around the testa or seed coats of dry legumes, the physical removal of seed coats by dehulling can decrease the condensed tannin content in legumes and can improve their nutritional quality (Ma and Bliss, 1979; Binyam et al., 1995). Rakic et al., (2007) also reported that the reduction of tannin after soaking and in combination with boiling and autoclaving is mainly due to the fact that those compounds in addition to their 
predominance in seed coats are water soluble and consequently leach into the liquid medium. The decrease could also be related to the fact that this compound is heat labile and degraded up on heat treatment.

The interaction effect of soaking time and temperature was significant $(\mathrm{p}<0.05)$ on condensed tannin content (Table 1). Based on the present result, the condensed tannins in soy flour soaked at $40^{\circ} \mathrm{C}$ for 16 hrs was significantly higher $\left(0.23 \mathrm{mg} \mathrm{CE} \mathrm{g}^{1}\right)$ than other treatments. But significant difference was not observed for soaking time $8 \mathrm{hrs}$ at $40^{\circ} \mathrm{C}, 12 \mathrm{hrs}$ soaking at $25^{\circ} \mathrm{C}$, and $40^{\circ} \mathrm{C}$ and $16 \mathrm{hrs}$ soaking at $25^{\circ} \mathrm{C}$. The results obtained for condensed tannins from processed flour were lower than raw soy flour $\left(0.29 \mathrm{mg} \mathrm{CE} \mathrm{g}^{1}\right)$. The tannin contents of both processed and raw soy flours were much more less than $18.6 \mathrm{mg} \mathrm{CE} \mathrm{g}^{1}$ reported by Fasoyiro et al. (2006) and less than the range (0.88 to $\left.2.06 \mathrm{mg} \mathrm{CE} \mathrm{g}^{1}\right)$ reported by Malencic et al. (2007).

In processed (soaked and dehulled) soybean most of the condensed tannin can be suppressed. However, the condensed tannin content was not totally eliminated after processing. Some condensed tannin might have leached into the soaking water and thus were detected in lower quantities in the beans. The reduction in condensed tannins content by soaking is a result of the fact that tannins are polyphenols and all polyphenolic compounds are water soluble in nature (Kumar et al., 1979). Therefore, reduction in condensed tannins content may be attributed to leaching out of phenols into the soaking medium under the influence of the concentration gradient (Vijayakumani et al., 1992).

Soaking in water at different time, germination, cooking or dehulling legumes, have direct effect on phenolic compounds. In legume grains, total phenolics had ranged from 0.9 to $33.7 \mathrm{mg} \mathrm{g}^{-1}$. Processing of grains led to variable effects on the extractable phenolics (Elifatio et al., 2003). Elifatio et al., (2003) reported that soaking, germination and cooking the grains can reduce the amount of total extractable phenolics while dehulling is the most effective method for reducing total extractable phenolics in legumes.

Table 1. Effect of soaking temperature and time on anti nutritional factors

\begin{tabular}{|c|c|c|c|c|c|}
\hline \multirow[b]{2}{*}{ Variables } & & \multicolumn{2}{|c|}{ Soy flour } & \multicolumn{2}{|c|}{ Soy milk } \\
\hline & & $\begin{array}{c}\text { Condensed } \\
\text { tannin } \\
(\mathrm{mg} \mathrm{CE} / \mathrm{g})\end{array}$ & $\begin{array}{c}\text { Phytic acid (mg g- } \\
\left.{ }^{-}\right)\end{array}$ & $\begin{array}{c}\text { Condensed } \\
\text { tannin } \\
(\mathrm{mg} \mathrm{CE} / \mathrm{g})\end{array}$ & $\begin{array}{c}\text { Phytic acid (mg g- } \\
1)\end{array}$ \\
\hline \multirow[t]{4}{*}{ Time } & Temp. & \multirow{2}{*}{\multicolumn{4}{|c|}{ Main effect of soaking temperature $\left(25\right.$ and $\left.40^{\circ} \mathrm{C}\right)$ and time $(8,12$ and $16 \mathrm{~h})$}} \\
\hline & & & & & \\
\hline & 25 & $0.06 \pm 0.04 \mathrm{~b}$ & $5.88 \pm 2.53 \mathrm{~b}$ & $0.11 \pm 0.03 b$ & $7.44 \pm 0.71 \mathrm{a}$ \\
\hline & 40 & $0.09 \pm 0.10 \mathrm{a}$ & $6.48 \pm 2.21 \mathrm{a}$ & $0.16 \pm 0.07 \mathrm{a}$ & $7.03 \pm 0.47 b$ \\
\hline 8 & & $0.07 \pm 0.04 \mathrm{~b}$ & $4.26 \pm 1.92 \mathrm{c}$ & $0.07 \pm 0.01 \mathrm{c}$ & $7.58 \pm 0.81 \mathrm{a}$ \\
\hline 12 & & $0.03 \pm 0.01 \mathrm{c}$ & $8.33 \pm 0.94 \mathrm{a}$ & $0.16 \pm 0.03 b$ & $7.43 \pm 0.34 \mathrm{a}$ \\
\hline 16 & & $0.13 \pm 0.11 \mathrm{a}$ & $5.94 \pm 1.94 b$ & $0.18 \pm 0.06 \mathrm{a}$ & $6.69 \pm 0.10 b$ \\
\hline Mean & & 0.07 & 6.17 & 0.14 & 7.23 \\
\hline \multirow[t]{2}{*}{$\mathrm{CV}$} & & 22.33 & 6.79 & 8.18 & 2.81 \\
\hline & & \multicolumn{4}{|c|}{ Interaction effect ( soaking time and temperature) } \\
\hline 8 & 25 & $0.11 \pm 0.01 b$ & $2.52 \pm 0.20 \mathrm{e}$ & $0.07 \pm 0.01 \mathrm{~d}$ & $8.31 \pm 0.04 \mathrm{a}$ \\
\hline 8 & 40 & $0.03 \pm 0.01 c$ & $6.00 \pm 0.14 \mathrm{c}$ & $0.07 \pm 0.01 \mathrm{~d}$ & $6.85 \pm 6.85 \mathrm{c}$ \\
\hline 12 & 25 & $0.04 \pm 0.00 \mathrm{c}$ & $7.49 \pm 0.17 b$ & $0.13 \pm 0.01 \mathrm{c}$ & $7.25 \pm 0.36 b$ \\
\hline 12 & 40 & $0.02 \pm 0.00 \mathrm{c}$ & $9.17 \pm 0.26 \mathrm{a}$ & $0.18 \pm 0.01 b$ & $7.60 \pm 0.25 b$ \\
\hline 16 & 25 & $0.03 \pm 0.01 \mathrm{c}$ & $7.63 \pm 0.32 b$ & $0.13 \pm 0.01 \mathrm{c}$ & $6.75 \pm 0.09 \mathrm{c}$ \\
\hline 16 & 40 & $0.23 \pm 0.03 \mathrm{a}$ & $4.26 \pm 0.88 \mathrm{~d}$ & $0.24 \pm 0.00 \mathrm{a}$ & $6.63 \pm 0.10 c$ \\
\hline Mean & & 0.07 & 6.17 & 0.14 & 7.23 \\
\hline $\mathrm{CV}$ & & 22.33 & 6.79 & 8.18 & 2.81 \\
\hline
\end{tabular}

$\mathrm{CV}=$ coefficient of variance, Values followed by different letters with in a column indicate significant difference $(\mathrm{p}<0.05)$, Mean $\pm \mathrm{SD} ; \quad$ Number of observation with in treatment $=3$

3.1.2. Phytic acid

Temperature was significantly $(\mathrm{p}<0.05)$ influenced phytic acid content of soy flour. At $40^{\circ} \mathrm{C}$ soaking temperature the phytic acid content of soy flour was higher $\left(6.48 \mathrm{mg} \mathrm{g}^{-1}\right)$ than the soy flour treated at $25^{\circ} \mathrm{C}\left(5.88 \mathrm{mg} \mathrm{g}^{-1}\right)$ (Table 4). These values were higher than raw soy flour $\left(4.11 \mathrm{mg} \mathrm{g}^{-1}\right)$ but lower than $\left(17.49 \mathrm{mg} \mathrm{g}^{-1}\right)$ reported for Awassa variety (Yimer, 2008). Differences in phytic acid contents may be due to the variety, climatic conditions, location, irrigation condition, type of soil and the year during which plants grew (Urbano et al., 2000). These results agreed with other results reported. Deshpade et al., (1982) reported that phytic acid content of soybean varies from 4 to $20 \mathrm{mg} \mathrm{g}^{-1}$ depending on the variety.

Time had significant effect $(\mathrm{p}<0.05)$ on phytic acid content of soy flour. Phytic acid in processed soy flour was higher $\left(8.33 \mathrm{mg} \mathrm{g}^{-1}\right)$ at $12 \mathrm{hrs} \mathrm{soaking} \mathrm{time} \mathrm{followed} \mathrm{by} \mathrm{the} \mathrm{value}\left(5.94 \mathrm{mg} \mathrm{g}^{-1}\right)$ measured for $16 \mathrm{hrs} \mathrm{soaking}$ and the lower (4.26 mg g ${ }^{-1}$ ) was obtained for 8 hrs soaking (Table 5). These values were also higher than the raw soy flour values. The increase of phytic acid contents after soaking and dehulling might be attributed to the cotyledon fractions of the beans or the seed coat which contributes a substantial portion of the whole seed 
weight. Removing the seed coat may lead to an increase in the concentrations of the anti nutrients. The increase in phytic acid content suggests that dehulling may improve the extraction efficiency of phytic acid from the beans. The current value obtained may be comparable to that of Yimer, (2008) who reported that the phytic acid levels of Awassa and Belessa varieties augmented by $8.90 \%$ and $41.36 \%$, respectively. The increase in contents of phytic acid after dehulling in agreement with the report of Deshpande et al. (1982) (16.9 to $59.8 \%$ ) for other legumes.

Interaction effect of soaking time and temperature was significant $(\mathrm{p}<0.05)$ on phytic acid content of soy flour (Table 5). Accordingly, the phytic acid in soy flour made from soaked soybean for 12 hrs with $40^{\circ} \mathrm{C}$ was significantly higher $\left(9.17 \mathrm{mg} \mathrm{g}^{-1}\right)$ phytic acid content was obtained and the lowest value $\left(2.52 \mathrm{mg} \mathrm{g}^{-1}\right)$ was recorded at $8 \mathrm{hrs}$ soaking time with $25^{\circ} \mathrm{C}$ soaking temperature. Phytic acid increased from 4.11 (raw) to $9.17 \mathrm{mg}$ $\mathrm{g}^{-1}$ which was measured from $12 \mathrm{hrs}$ soaking time with $40^{\circ} \mathrm{C}$ soaking temperature. This might be due to the leaching out effect during soaking and reabsorbed by the seed. The result was agreed with the value reported Egounlety and Aworh, (2003) who observed that soaking of soybean for $12 \mathrm{hrs}$ to $14 \mathrm{hrs}$ which increased the level of phytic acid from raw $12.7 \mathrm{mg} \mathrm{g}^{-1}$ to $17.1 \mathrm{mg} \mathrm{g}^{-1}$ and; dehulled and cooked to $15.4 \mathrm{mg} \mathrm{g}^{-1}$. Alonso et al., (2000) reported that Phytic acid in raw bean $\left(16.58 \mathrm{mg} \mathrm{g}^{-1}\right)$ in dehulled bean $\left(18.68 \mathrm{mg} \mathrm{g}^{-1}\right)$. Soaking and dehulling may lead to an increase in the concentrations of phytic acid. Soaking may improve the extraction of phytic acid from the beans. Generally the amounts of phytic acid of soy bean reported by different investigators were inconclusive. Elifatio et al., (2003) reported that the phytic acid content of legumes is different and most of it is present in the outer aleurone layer of the seed.

The increase in phytic acid content of the soy flour observed in this study may be attributed to the dehulling process employed. Since the seed coats were removed manually in the present investigation, few changes were expected in the composition of the aleurone layers, which may be attributed to the accumulation sites of phytic acid in legumes. Consequently, increment of phytic acid content through the removal of hulls would be apparent. It may be desirable to maintain a low level of phytic acid in soybean foods by appropriate processing procedures or by modifying the plant itself so that less phytate accumulates during seed maturation, or genetic selection for beans with low phytic acid content may aid in increasing the utilization of legumes with respect to mineral bioavailability and improving nutritional quality of soybean.

\subsection{Effect of Soaking Temperature and Time on Anti-nutritional Factors of Soybean Milk 3.2.1. Condensed tannins}

Soymilk condensed tannin was significantly $(\mathrm{p}<0.05)$ affected by soaking temperature (Table 5$)$. Condensed tannin was significantly higher $\left(0.16 \mathrm{mg} \mathrm{CE} \mathrm{g}^{-1}\right)$ which were obtained from $40^{\circ} \mathrm{C}$ soaking temperature than $25^{\circ} \mathrm{C}$ $\left(0.11 \mathrm{mg} \mathrm{CE} \mathrm{g}^{-1}\right)$. The value exhibited increasing in condensed tannin as the soaking temperature increased. The result showed that exposure of soy bean to hot temperature increased the degradation of structural components made it weak to lose anti nutrients and might be reactivated.

Soy milk condensed tannin was significantly $(\mathrm{p}<0.05)$ influenced by the soaking time in Table 5 . At 16 hrs soaking time significantly higher value $\left(0.18 \mathrm{mg} \mathrm{CE} \mathrm{g}^{-1}\right)$ was obtained and the lower value $\left(0.07 \mathrm{mg} \mathrm{CE} \mathrm{g}^{-1}\right)$ was observed from 8 hrs soaked soybean. The condensed tannin content was increased with increase soaking time. This probably due to in longer soaking time, some tannin leached into the soaking water and thus were detected in lower quantities then reabsorbed by the soybean. Trongpanich et al., (1988) reported that prolonged soaking time increased enzyme activity and results change the composition of soymilk.

Soy milk condensed tannin was significantly $(\mathrm{p}<0.05)$ affected by interaction effect of soybean soaking time and temperature. The condensed tannin content was higher $\left(0.24 \mathrm{mg} \mathrm{CE} \mathrm{g}^{1}\right)$ on soybean soaked for $16 \mathrm{hrs}$ at $40^{\circ} \mathrm{C}$ (Table 5). The condensed tannin content of soy milk appeared to increase with increased in the soaking time at $40^{\circ} \mathrm{C}\left(0.07,0.18\right.$ and $\left.0.24 \mathrm{mg} \mathrm{CE} \mathrm{g}^{1}\right)$. This might be due to higher soaking temperature with longer period which can affect the molecular structure of tannins and polyphenols. This chemical modification might be altered the solubility of tannins or chemical reactivity.

\subsubsection{Phytic acid}

The soy milk phytic acid was significantly affected by soaking temperature. At $25^{\circ} \mathrm{C}$ soaking temperature higher ( $7.44 \mathrm{mg} \mathrm{g}^{-1}$ ) phytic acid content was recorded as compared to $40^{\circ} \mathrm{C}\left(7.03 \mathrm{mg} \mathrm{g}^{-1}\right)$. The phytic acid content was decreased as the soaking temperature increased. The decrease phytic acid results were comparable to data reported for other soybean varieties (Alonso et al., 1998). Soaking time significantly affected soy milk phytic acid. The lower value $\left(6.69 \mathrm{mg} \mathrm{g}^{-1}\right)$ occurred after soaking the soybean for $16 \mathrm{hrs}$ (Table 5). There was no significant difference between 8 and $12 \mathrm{hrs}$ soaking time. The soaking time increased from 8 to $16 \mathrm{hrs}$, the phytic acid content decreased to $\left(7.58,7.43\right.$ and $\left.6.69 \mathrm{mg} \mathrm{g}^{-1}\right)$. The greater decrease at $16 \mathrm{hr}$ soaking condition might be because of prolonged soaking time which caused more phytic acid diffuse into the soaking water.

Similarly, soy milk phytic acid was significantly affected by the interaction effect of soybean soaking time and temperature. Phytic acid content $\left(8.31 \mathrm{mg} \mathrm{g}^{-1}\right)$ was measured for soaking for $8 \mathrm{hrs}$ at $25^{\circ} \mathrm{C}$. But no difference between at $8 \mathrm{hr}$ soaking time with $40^{\circ} \mathrm{C}, 16 \mathrm{hr}$ with $25^{\circ} \mathrm{C}$ and $40^{\circ} \mathrm{C}$. When soaking time increased from 8 to 16 
hrs, the phytic acid content was decreased to $8.31,7.25$ and 6.75 at the soaking temperature of $25^{\circ} \mathrm{C}$. This reduction in phytic acid content may be attributed to leaching out of phenolic compounds into the soaking medium due to longer soaking time.

\section{Conclusion}

The current study revealed that soaking time and temperature on antnutrients. Optimum processing time and temperature was important for reducing the anti-nutritional factors without affecting the nutritional quality. Processing included soaking and dehulling significantly reduced condensed tannins content in soy flour and milk whereas phytic acid was increased. The most accepted soybean flour and milk was produced from soy bean soaked at $8 \mathrm{hrs}$ with $40^{\circ} \mathrm{C}$ in all parameters.

\section{References}

Stauffer, C. E., 2008. Soy flour products in baking, Technical Foods Consultants, Nigeria, retrieved from http://www.wishh.orgnizational nutrition staufer-baking-paper.pdf on November 2008.

Steinkraus, K. H., 1979. Microbiology of foods produced in Tropical Asia. In S. Saono, and F. G. Wirnano (Eds.), Proceedings of International Symposium on Microbiological Aspects of Food Storage, Processing and Fermentation in Tropical Asia. Indonesia: Bogor. pp. 12-22.

Suberbie, F.D. Mendizabal and C. Mendizabal, 1981.Germination of Soybeans and its Modifying Effects on the Quality of Full-fat Soy Flour. Journal of American Oil Chemistry. 58:192.

Sucan, M.K., 1987. Identifying and preventing off-flavors. Journal of Food Technology. 58, 36, 85.

Sudarmadji, S. and P. Markakis, 1977. The phytate and phytase of soybean tempeh. Journal of the Science of Food and Agriculture, 28, 381-383.

Swain, T., 1979. Tannins and lignins. In: Rosenthal G. A., Janzen, D. H. (eds.).Herbivores, their Interaction with Secondary Plant Metabolites, 57-68. Academic Press, New York.

Taylor, A. J. and S.T. Linforth, 1996. Flavor release in the mouth. Trends in Food Science and Technology, 7: $444-448$

Taylor, A. J., 1996. Volatile flavor release from foods during eating. Critical Reviews in Food Science and Nutrition, 36: 765-784.

Trongpanich, K., M. Yunchalard, O. Chaiprasop and C. Vittavatwong, 1988. Effect of food additives and soybean quality on quantity of protein and quality of concentrated soybean milk. Food Journal 18 (4): 45.

Tunde, A. T.Y. and A. Souley, 2009. Effect of Processing Methods on Quality of Soymilk. Pakistan Journal of Nutrition. 8 (8): 1156-1158,

Urbano, G.L., Jurado, M. Aranda, P.VidalValverde, C. Tenorio and J. Porres, 2000. The role of phytic acid in legumes: anti nutrient or beneficial function. Journal of physiological Biochemistry, 56: 283-294.

Varma, P.and U. Mehta, 1988. Study of physical characteristics, sensory evaluation and the effect of sprounting, cooking and dehulling on the antinutritional factors of rice bean (Vigna umbellate). Journal of Food Science and Technology. 25 (9): 197.

Vasconcelos, I.M., E.A. Siebra, A.B Maia, R.A. Moreira, A.F. Neto, G.J. Campelo and J.T. Oliveira, 1997. Composition, toxic and antinutritional factors of newly developed cultivars of Brazilian soybean (Glycine max). Journal of Science and Food Agriculture, 75: 419 - 426.

Vijayakumari K, P., K. Siddhuraju and K. Janardanan, 1995. Effect of various water treatments on certain antinutritional compounds in the tribal pulse, Dolichos lablab var vulgaris L. Plant Foods and Human Nutrition. 48: 17- 29.

Vijayakumari,K. P., K. Siddhuraju and K. Janardhan,1992. Effect of processing on the levels of certain antinutrients in Proscopis chilensis. Food Chemistry., 59: 367-370.

Waiker, M. T., M. Mehta, 1977. Palatability score, nutritional value and tripsin inhibitor activity of some common soybean substituted recipes. Australia. P.78

Wang, N., M.J. Lewis, J.G. Brennan and A. Westby, 1997. Effect of processing methods on nutrients and antinutritional factors in cowpea. Food Chemistry, 58, 59-68.

Wang, T. L., C. Domoney, C. L. Hedley, R. Casey and M.A. Grusak, 2003. Can we improve the nutritional quality of legume seeds? Plant Physiology, 131, 886-888.

Wilkens, W.F and L.R. Hackler, 1967. Effect of Processing Condition on the Composition of Soy milk. Cereal Chemistry 46: 391.

William,P., F.J. El-Haramein, H.Nakkoul and S. Riharwi, 1986. Crop quality evaluation methods and guide lines. International center for Agricultural Research,in thDry Area of Aleppo,Syria.

Wolf, W.J., 1988, Effect of agricultural practices, handling, processing and storage on legumes and oil seeds, in Karmas, E. and Harris, R.S. (Eds), Nutritional Evaluation of Food Processing, AVI Publications, New York, NY, pp. 119-121.

Wrigley,C., H. Corke and C. Walker, 2004. Encyclopedia of Grain Science, Vlo.III. P. 185-188. 
Yadav, S., and N. Khetarpaul, 1994. Indigenous legume fermentation: effect of some anti-nutrients and in vitro digestibility of starch and protein. Food Chemistry, 50, 403-406.

Yanez, E., D. Ballester, D. Aguey and H. Way, 1982. Enrichment of bread with soybean flour. Archives catinoamenconus. Journal of Agriculture. 22 (4): 937-938.

Yimer Assefa and Admassu shimelis, 2008. Effect of Processing on Some Anti nutritional Factors of Improved Soybean (GLYCINE MAX) Varieties Growth in Ethiopia Msc thesis, Adis Abeba University.

Zampini, M., D. Sanabria, N. Phillips and C. Spence, 2007. The multisensory perception of flavor: assessing the influence of color cues on flavor discrimination responses. Food Quality and Preference, 18 (7):975-984.

Zenk, H.M., 1991. Chasing the enzymes of secondary metabolism: Plant cell cultures as a pot of goal. Phytochemistry, 30 (12): 61-63. 